Portland State University

PDXScholar

11-13-1973

\title{
Differences Between Supervisor and High and Low- Rated Employees' Perceptions of Job Performance Ratings and Importance of Job Factors
}

Harvey Edward McGowan

Portland State University

Follow this and additional works at: https://pdxscholar.library.pdx.edu/open_access_etds

Part of the Industrial and Organizational Psychology Commons

Let us know how access to this document benefits you.

\section{Recommended Citation}

McGowan, Harvey Edward, "Differences Between Supervisor and High and Low-Rated Employees' Perceptions of Job Performance Ratings and Importance of Job Factors" (1973). Dissertations and Theses. Paper 2052.

https://doi.org/10.15760/etd.2051

This Thesis is brought to you for free and open access. It has been accepted for inclusion in Dissertations and Theses by an authorized administrator of PDXScholar. Please contact us if we can make this document more accessible: pdxscholar@pdx.edu. 
AH ABSTRACI OF MHE THESIS ON Harvey Edward NoGowan for the Master of Science in Psychology preserted February 8, 1974.

Title: Differences between Supervisor and High and Lowreted Employees' Perceptions of Job Performance Ratings and Importance of dob factors.

APPROVED BY MEMBERS OF THE THESIS COMITTEE:

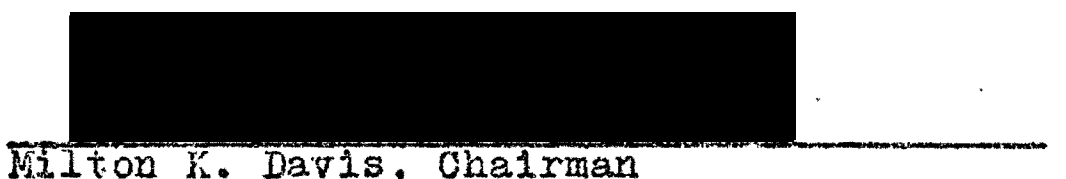
MItion K. Davis, Chalrman

Róbert F. Powioshi

This study was an attempt to gain insight lato difo ferlag conceptions of job performance and fob performance factors held by supervisors, employees in general, and of employees rated high and low on overali job performance by their supervisors. The discrepanoy in the perceptions of job performance is an element in a general pattern of a well-aocumented aiscrepancy in the perception of subordinates' wats, needs and desires by superiors. 
To assess employees' perceptions about their own job performance, self-ratings were takex, along with estimate ratings of how employees thought their supervisors would rate them. A graph1c rating scale was used, Format III, with seven job performance factors; Ability to work with others, Amount of work done, Quality of work done, Leadership potential, Ability to do complicated jobs, Ablilty to work with minimum supervision, conscientiousness, and an eighth scale, overall Performance. Subjects were 78 female assembly workers along with their elght immediate male supervisors.

It was hypothesized, on the basis of earlier studies, that employees would rate themselves higher than their estimate ratings, which, in turn, would be bigher than actaul supervisor ratings. This general ordering was found to be slgnificant for all factors except 1,2 and 3 at the .05 level and beyond. The ordering of scores on scaie 8 , Overall performance, was significant at the .01 level.

Differences were explored among groups of employees In the degree of discrepancy between estimate ratings and supervisors' ratings. Employees were divided into high and low groups according to ratings given them by their supervisors; both groups consisting of one-third the total number of employees. It was hypotinesized that low-rated employees would show more discrepancy than would highrated employees, and both groups would overestimate their 
overall pexformance.

Though the discrepancies for the two groups were In opposite directions (higher group underestimating, lower group overestimating), the difference in the absoIute amount of discrepancy did not approach significance. The lower group did not show significantly more discrepancy as predicted. Also, the high group rated themselves and estimated their ratings significantly lower than actual supervisors' ratings.

The third hypothesis was based on the assumption that high-rated employees are so rated partly because the relative importance these employees attach to job factors Is more similar to that attached by supervisors than are those by low-rated employees. Nultiple regression equations were computed for supervisors' ratings, high-self ratings and low-self ratings using the overall performance rating as the criterion and the other seven factors as predictors. As predicted, high-rated employees demonstrated closer correspondence in their welghts to those given by supervisors than did low rated employees. Conclusions based on the study, Iimited by nature and number of subjects and the type and number of factors used: in the rating scale rere as follows; a) employees, as a wole, rate themselves higher both on self-ratings and on estimates of their supervisors' ratlugs than the supervisors actualiy do rate them, b) nelther higi nor low-rated employees have any better ldea 
of how their supervisors rate them on overall performance; both groups show approximately the same amount of discrepancy between their estimate of their supervisor's ratings and the actual ratings with high-rated employees underestimating themselves and low-rated employees overestimating themselves on overall performance, d) high-rated employees seem to have a better 1 dea of the job factors considered important in their contribution to overali performance by supervisors than do low-rated employees; the factors hlgh-rated employees judge as important axe generaliy the same factors their supervisors judge as important with a few notable exceptions. 
DIFFERENCES BETWEEN SUPERVISOR AND HIGE AND IOW-RATED BMPLOYEES' PEROEPTIONS OF JOB PERTORMAMOE RATINGS AND IMPORTANCE OF JOB FAOTORS

\author{
by \\ HARVEY BDWARD MCGCWAN
}

A thesis submitted in partial fulfiliment of tine requirements for the degree of

\author{
MASTER OF SCIENCE \\ in \\ PSYOHOIOGY
}

Portland State University

1973 
TO THE OFIICE OF GRADUATE STODIES AND RESEARCH:

The nembers of the Comrittee approve the thesis of Harvey Edwara McGowan presented November 13, 1973.
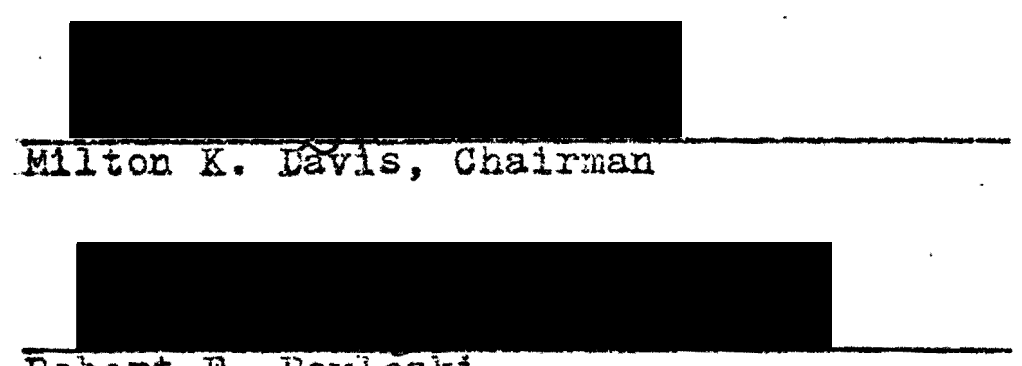

Eobert F. Powloskj.

Janes A. Poulson

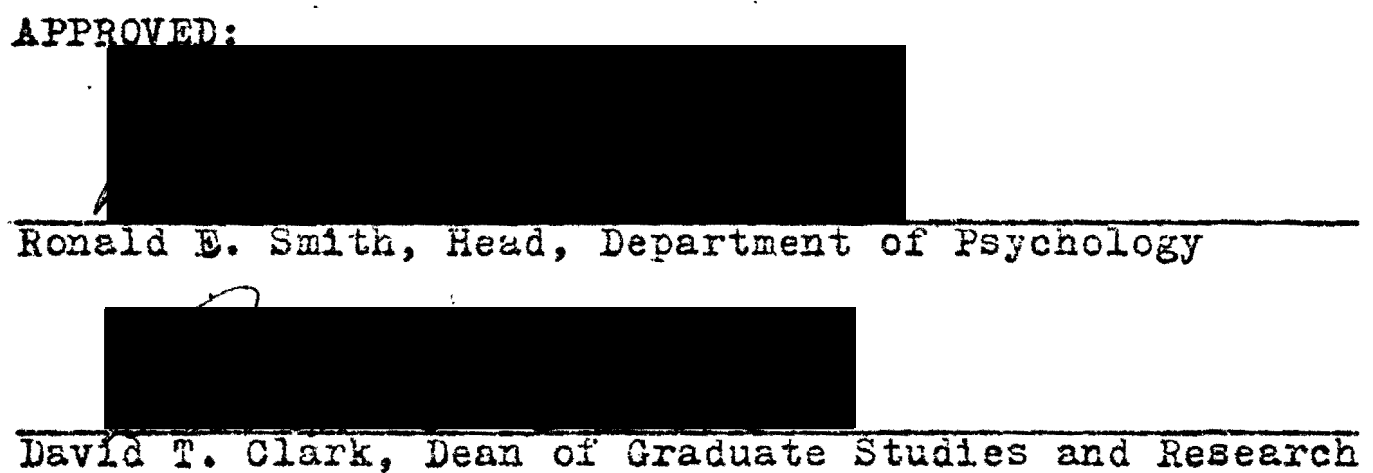




\section{ACKNOWLEDGEMENTS}

I am Indebted to a number of inaividuals rithout whose time and efforts, the completion of this project would have been questionable; to Dr. Milton Dav1s, my the81 advisor and cormittee chairman, who has lent his wisdom and guldance to the development of this study from 1ts Inftial stages; to Drs. Robert Porlosk1 and James Paulson, whose helpful suggestions and criticisms aided in the formulation of methodology and analysis; to Mr. Ed Srebnik and Jack Morehouse of Tektronix, Inc. Who so willngly and enthusiastically demonstrated their support for personnel research by arranging the avaliability of employees and the facllities for collection of data; to those women at Tektronix who contributed their time, efforts and, in some cases, their coffee breaks, so that ome stranger from Pcrtland State Unlverglty might conduct a bit of research; and, of course, to my wife Kathy, whose support, encouragement and understanding have never falled me. 


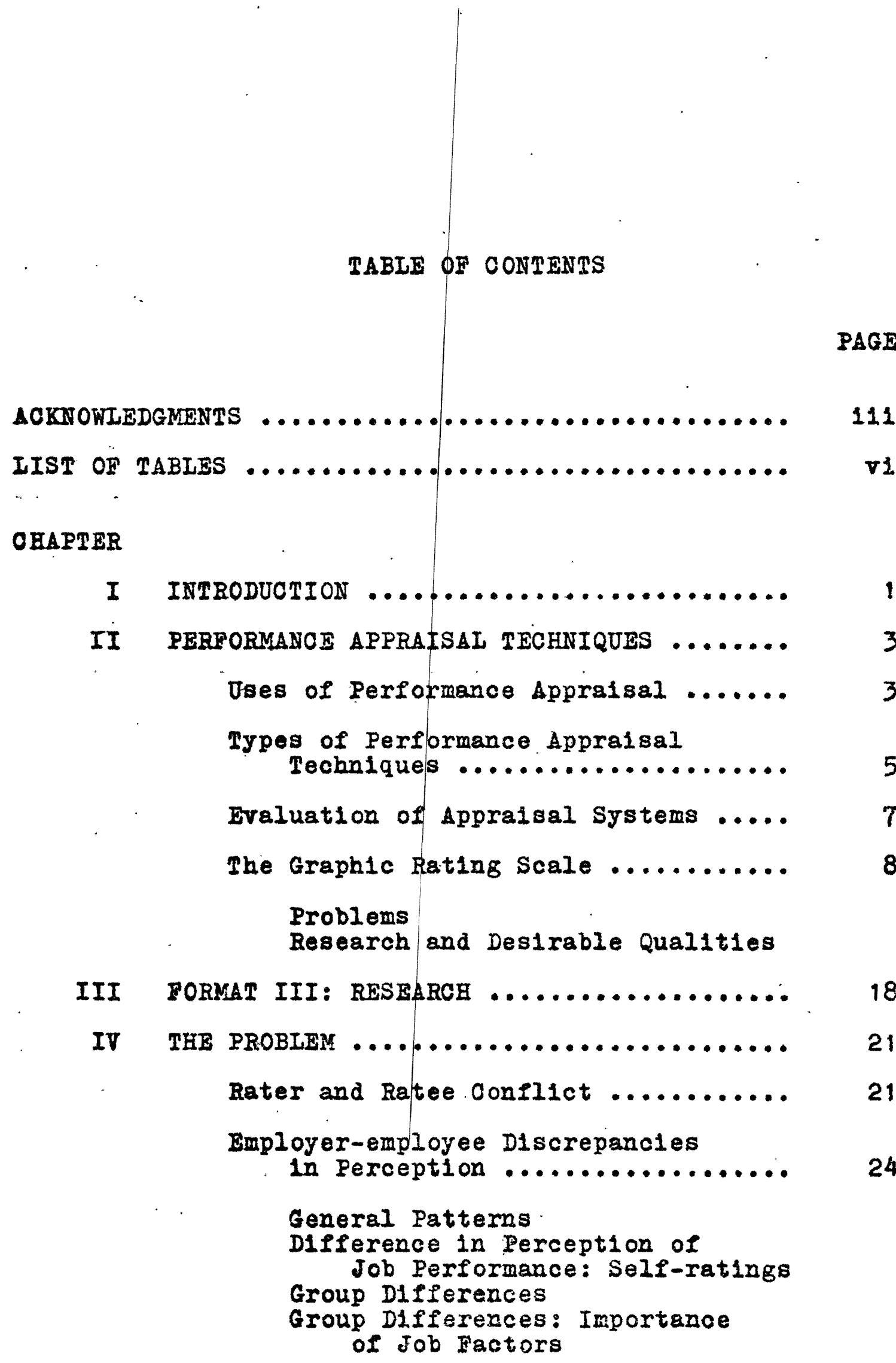

Statement of Hypotheses ........... 32 
OHAPIER

PAGE

v METHOD ............................. 34

The Rat1ng Form ................ 34

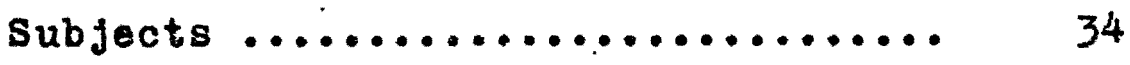

Procedure ............................ 35

Scor1ng

VI RESUITS ........................... 37

Hypothes1s I .................. 37

Hypothesis II .................. 38

Eypothesis III ................. 40

vII DIscussION ......................... 51

Implications of the study ......... 51

Ilmitations of the study .......... 56

Recommendations for further research. $\quad 57$

VIII $\operatorname{sUMMARY} \ldots \ldots \ldots \ldots \ldots \ldots \ldots \ldots \ldots \ldots \ldots \ldots \ldots \ldots \ldots \ldots$

RERERENOES ............................... 65

APPEHDIX A .............................. 68

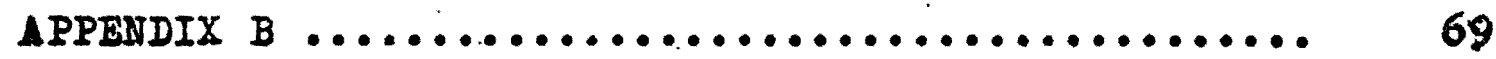




\section{IIST OF TABLES}

TABLE

PAGE

I Means and standard devlations of scale

scores of three types of rating using

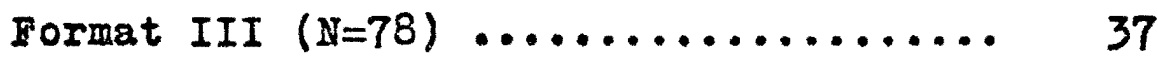

II Ratings on Factor 8 for upper and lower

th1rd emplojees .................

II Correlations between ratings on Factor 8

for upper and lower third emplojees ... 40

IV Summary of stepwise regression analysis of

ratings by high-rated employees ...... 42

$\nabla$ Summary of stepwise regresiton analysis of

ratings by low-rated employees .......

VI Summary of stepwise regression analysis of ratings by supervisors ............. 44

VII Beta-weights for each factor with multiple correlations (R) between Ractors 1 through 7 with Factor $8 \ldots \ldots \ldots \ldots \ldots$ 


\section{CHAPTER I}

\section{INTRODUOTION}

The assessment of human behavior is a problem not exclusively confined to the psychologist or to the realm of psychology. It 18 quite apparent that psychologists are not the only people involved in the formal measurement or evaluation of human behavior. Educators, for example, are asked to periodically assess the behavior of their students in a systematic, written manner. These assessments are, of course, subject to the same imperfections and failings of all measurements of human behavior, but nonetheless serve an immediate purpose and affect the I1ves of a good many inaividuals. Those engaged in the management and supervision of human behavior in an industrial setting also attempt to formally assess the behavior of individuals. Inls latter form of assessment is, in part, the subject of this study; a form of assessment whlch not only possesses all the shortcomings of measurement techniques in general, but also has inherent imperfections and yields an uncanny influence over the lives of mlilions of working men and romen.

As Tiffin and Mecormick (1965) point out, the rating of working men by their aupervisors is by no means a recent development. Supervisors have always rated thelr workers, 
and these ratings, however slipshod and unsystematic, have always had enormous influence on personnel decislons. portunately, they have become increasingly more sophist1cated, resulting, among other things, in more comparability from one employee to another. Formal rating systems have not ceased, however, to be a source of continuing controversy. It is a basic tenet of human nature and psychology that human belngs do not percelve all things similarly. It would be expected, then, that a ratee would have a very different perception of his fob performance than would a rater, by the very fact they are different human beings with different values, expectations and viewpoints. The nature and degree of this discrepancy between rater and ratee and the consideration of group differences among ratees is the subject of this study. 
CBAPTER II

PERFORMANCE $\triangle$ PPRAISAL TEOHNIQUES

I. USES OF PERFORMANOE APPRAISAL

Paychologists develop measures of human behavior primarily to understand more about the behavior being assessed or measured. When these same measuring techniques are used in an applied situation, they are often implemental In making practical declsions about human beings. Th1s is certainly the case with merlt rating systems. Understandably, analyzing the behavior of employees is secondary to obtaining a measure of their performance and making decisions based on that measure. This fact becomes more appa:rent when one looks at the frequency with which merit rating systems are used for administrative purposes as compared w1th research purposes. The National Industrial Board (1954) found that, of those companies surveyed which were using some sort of rating system, $72 \%$ used them in the adminiatration of wages, 63\% for identifying promotable employees, while only 22\% used them for any kind of research. Barrett (1966) liste three general purposes for which rating systems find use in industry: administrative--prograns directed at some immediate personnel action such as salary determination, 
promotion or layoff; performance improvement--primarily through supervisory review and research; and research-particularly to ascertain the value of selection and trainIng procedures. As might be expected, the primary general purpose of rating systems is administrative, according to Barrett, with salary administration being the single most important use. Benjamin (1952) also found the single most common use of ratings to be in connection with merlt pay 1ncreases.

Although rating systems are used for other purposes such as employee self-improvement, to determine training needs among employees, and to sort special talents among employees, the fact remalns that merit rating systems are, by thelr very nature, evaluative. Merit rating systems attempt to directiy determine an individual's value or usefulness in a particular organizational setting. While an intelifgence test might demonstrate to an individual that he does not possess some skills which society tends to value, it does not make direct, evaluative statements about his worth as a functioning human being in a setting that is tied to his very livelibood. While rating systems are used for a variety of reasions which may differ from company to company, the primary purpose of these systems is the determination of a particular employee's worth to the company, a determination upon which is based the administration of wages and the fudgment of promotablilty. 
II. TYPES OF PERFORMANCE APPRAISAI TECHNIQUES

Just how is the effectiveness of employees ourrentIy measured in industry? A brief description of various methods of performance appraisal or merit rating systems follows:

\section{Graphic Rating Scales}

The most widely used method in which a serles of trait names, factors or characteristics are listed and a mark of some kind is placed on a line or at intervals which represent the degree to which the item is exhibited or possessed by the individual being rated.

\section{Rank Order Method}

W1th this method, all employees rated by the superv1sor are ranked from best to poorest in one or more tralts.

\section{Forced Distribution Method}

Individuals are distributed along one or more scales and a fixed percentage is assigned to the best and worst ends of the distribution as well as to the middle bracket of the distribution.

\section{Paired Comparison Method}

For each tralt every subordinate is compared w1th every other subordinate and the number of favorable cholces 18 tallied for each individual. 
Critioal Ineident Method

Thls system involves the keeping of a record of unusually good or undesirable incldente occuring in an employee's wort.

\section{Porced Choice Method}

Sets of descriptive statements are given and the rater selects those which are most and least descriptive of the employee.

Pree Written Essay

Someone in a position to know the ratee's work or performance is asked to describe that performance and evaluate it.

\section{Object1ve Measures}

The most easily measured aspects of performance such as sales, smount of pleces produced, or scrap rate are used 28 a basis of evaluation.

\section{Welghted Random Checklists}

A serles of brlef descriptive phrases are arranged that have been scaled in favorableness and assigned scoring weights not known to the rater who checks 1 tems which apply to the Individual belng rated, leaving others blank. The total valua of those items checked plus a correction factor gives the final rating score. 
Bach of these methods has advantages and disadvantages of their own. Generally, it can be sald that these methods, by one means or another, attempt to compare individuais w1th one another or with some objective scale. The most widely used metrod, the graphic rating scale, has certain advantages in that it allows comparison not only with a presumably objective scale on any number of traits or characteristics, but also allows comparisons among lndividuals rated on the same sclae. No other rating system allows this. For these reasons and others, this method of evaluation wes chosex for use in this study.

\section{EVALUATION OF APPRAISAL SYSTEMS}

The basic question one must ask about any measuring devica, whether 1t be a yardstick, an aptitude test, or a mer1t rating system, is "Does it measure accurately?". This question becomes increasingly more difficult to answer concerning any device which purports to measure facets of human behavior. Fortunately, in the process of developing techniques of measuring behavior, behavioral scientists have developed fairly sophisticated methods for determining an instrument's value; how stable the instrument 1s, how susceptible it 18: to random variables, and how well it corresponds to other instruments or, in a practical situation, to certain desirable criteria.

The evaluation of merit rating systems in industry 
poges special problems. For one, merit rating systems usually are not orlginated by people concerned with scientific methods, but rather by a pragmatic industrial management who desire a fast, somewhat permanent evaluation of buman beings as units which expend certain amounts of energy in contributing organizational goals. If a merit rating system seems to serve these purposes and does not seem to be grossly inaccurate, then there is no reas on to change the system. Thus, rating systems are not generaliy submitted to the same rigorous tests that other devices are, and so are denled a process of development and refinement. Another problem is that there exist few criteria outside the ratings themselves with which merlt ratings can be compared for purposes of validation. Merit rat1ngs themselves are used as criteria in a great many studies in personnel and industrlal psychology.

\section{IHE GRAPHIC RATING SCALE}

As stated above, a graphle rating scale was chosen for use in this study because of certaln advantages it possesses over other rating systems. It allows us to examine a quantitative measure of the degree to which an individual 1s attributed with a certain trait or factor. Furthermore, eince individuals are rated using the same scale, they can be compared to one another. Scores on each of the several tralts or characteriatics used can be compared to general, 
overall measure of employee performance. Conceivably, the contribution of certain factors to general job performance could be assessed and group differences be explored in this respect. Not the least of the advantages of using this particular form of appraisal is the fact that it probably possesses the largest backlog of related research of any rating system, and, as a result, has gone through a process of revision and refinement.

Problems

There are a few basic problems inherent in the graphic rating scale which a good number of researchers have invest1gated.. There is the familiar "halo" effect of which Thorndike (1920) remarked, "ratings are apparently affected by a marked tendency to think of a person in general as rather good or rnferior and to color judgments by this general feeling." If the halo effect is at work in the ratings, there results a higher correlation among traits than would be expected otherwise. Generally, it is held that this effect terids to detract from the accuracy of the rating scale. However, some investigators, including Bingham (1939), belleve that the effeet is not really as notorious as is commonly held. He states that a simllar effect is present In the perceptual process and in the act of judgment about any human being. It is unreasonable, he asserts, to expect raters to give a pure evaluation of each factor by itself, since all traits and characteristics of an individual 
combine in determining how an individual's personality is seen by others. Nevertheless, one method has often been ouggested (Barrett,1966 and Tiffin and McCormick, 1958) to eliminate or at least subdue the halo effect. This method involves baving the raters rate each individual on a particular trait before moving on to the next trait. This system supposedly forces the rater to think of one tra1t as possessed by each individual, one at a time, Instead of thiking of the whole person. Taylor and Hastman (1956) compared this method with the traditional method of rating an Individual on all traits before going on to the next 1ndividual. They found the results of the two methods to be essentlaaly the same and suggested that the traditional method be used over the more involved and time consuming alternative method.

Another inherent problem of graphic scales is commonIy referred to as the error of central tendency. This 18 the tendency of raters to use the center of the scale and to avold extremes. Although that beling rated is generally assumed to be normally distributed, involving a majority of the cases clustered around the mean of the distribution, the effect of central tendency is to assign more cases to the middle section than is actually warranted. It is difficult, of course, to determine which ratings actualiy belong there from those placed there for another reason. Generally, it is held that, as Barrett (1966) states, the 
error of central tendency occurs when the rater is unsure about what is being rated or does not have sufficient knowledge about the ratee's behavior to make any valid judgments about 1t. Ihe unwritten rule seems to be, "when in doubt, use the middle." - So the solution to this problem of central tendency rould seem to be to remove the doubt. This can be accomplished to some degree by first eliminating Erom consideration those with whose behavior the ratee is unfamiliar, and by making it clear what type of behavior is representative of the points on the scale. ilt 1 s hoped that the error of central tendency can be minimized by the use of such methods.

There exists another tendency on the part of raters to rate the majority of ratees as being above average. This tendency, referred to as the leniency effect, is oftentimes the result of personality factors within the individual dolng the rating rather than a result of something within the rating system 1tself. This tendency becomes more pronounced when it is known that the ratee w1ll see the rat1ngs or when it is known that the ratings will directly or indirectly influence the future of the ratee. Although leniency can probably never be ellminated completely (educators have forever been plagued with the " $c$ " student being inevitably below average), there are measures that can be taken to assure that this tendency can at least be minimized. This can be accomplished quite easily when the ratings are to be 
used in research by assuring that the rating will be kept confldential and w11l not be used in making decisions about those being rated. It is hoped that this will enable the raters to be more candid and truthful in their ratings than In the typical circumstances surrounding merit ratings.

\section{Research and Desirable Qual1ties}

Thus far, we have seen some of the problems associated with the graphic rating scale and how these problems might be minimized, if not completely eliminated. These have been problems connected with almost any kind of graphic rating scale. There are, of course, some scales or types of scales constructed in such a manner that they minimize any problems and also retain that quality which every measure of human behavior must possess; namely, rellability. According to the old rule of thumb, if a measuring device is not first rellable, 1t can never be valid. As was discussed above, validity is a special problem for merit rating systems and 18 beyond the scope of this study. And 80, as a result;: $\therefore$ we should be concerned with rellability and should choose a type of rating scale which has been show to possess a satisfactory amount of reliability. We should also explore other quallties that a rating scale should possess which eventually would be considered in the final cholce of a rating scale for use in this study. .:.

Graphic rating scales can alffer from one another on a number of dimensions or qualities; some of which are the 
number of tralts or factors to be rated, number of rating scale categorles, and type of scale anchoring. Any graphic rating scale used in research or in a practical situation should embody those characteristics which have been shown to be superior.

Empirical attempts to deterine the number of factors related to job performance have been somewhat inconclusive. Evart, Seashore, and Tiffin (1941) performed a factor analy$81 s$ on the results of a 12 tralt merit rating scale used to rate 1120 men and found only two factors; ability to do the present $j o b$ and the possession of skills above the requirements of the job. A third factor, health, was regarded by the Investigators as an "artifact". Roach (1956) had managers describe supervisors using a 390 1tem checklist questionnaire and, using factor analysis, found 15 factors. Grant (1955) asked supervisors to rate managers on an assignment-type rating scale with 20 assignments or job requirements listed and found one "general" factor and five "group" factors. These examples are enough to 1llustrate briefly the lack of agreement concerning the true number of factors involved. Seashore, Indik and Georgopoulos (1960) conclude that there is l1ttle support for the notion that there may exist some generalizable pattern or set of patterns describing the composition of job performance and the relationship among components of job performance. They point out that the relationships among different aspects of 
job performance are generally small and that the size and direction of these relationships are, to a large degree, unlque to each population and situation, and somewhat different for organizations as opposed to individuals.

The question arlses as to whether one should, in choosing the number of factors to be rated, pay heed to the confusing state of research on job performance factors. It is doubtful whether an employee's job performance aan be thoroughly assessed using as few as two factors. On the other hand, ratings requested on as many as 15 factors might well create a difficult and confusing task for raters with questionable results. Indeed, the majorlty of rating scales contain between flve and elght factors. The advice Given by Bittner (1950) seems sensible and appropriate. He states that traits or factors should be selected on the bat s1s of the following; observability-can the rater actually observe the trait?, universality-1s it an importnat characteristic of successful performance on all jobs to be rated?, and distinguishability-1s the trait clearly distinguishable as meaning something different from another trait with another name?. These three general criterla have been considered in the present study in the oventual choice of a rating scale.

In an early article, Symonds (1924) used a statistical argument to assert that, in regard to the number of pating categories to be used in a rating scale, rellablilty 
should increase somewhat with the number of categorles, but negligibly so when more than nine categorles are used. Bend18, however, in two studies $(1953,1954 a)$ varled the number of rating scale categories and compared rater rellability. In the first study, he compared scales using $3,5,7,9$ and 11 categories. He found essentially equal reliabilities for: all numbers of categories with the exception of the scale using eleven categories, in which case rellability decreased somewhat. In the second study, he compared $2,3,5$ and 7 categorles and again found no conslstent relationship between number of categorles and reliability. He maintalns that Symond's argument may hold true for test reliability, while it is rater reliablilty which is the concern of most people who investigate rating scale methods. Apparently, It can be said that the number of rating scale:categories has little influence on rater rellabllity.

In his first study, Bendig also varied the amount of verbal anchoring, or verbal descriptions of the points on a rating scale. Three conditions were compared; the center category was delined, both end categories were defined, or both end and centex categories were defined. He found that the rellability of the scale increased with the amount of verbal anchoring. Peters and McCormick (1966) compared the rellabllity of numertcally anchored scales with that of verbally anchored scales. Ratings were made on five sensory/phyolcal dimensions of job activities. Reliabilities: 
for all scales were computed by the analysis of variance approach. "In a test of statistical signiflcance across all I1ve dimensions, it was found that job-task anchored scales could generally be used with significantly greater rellabiIIty than numerically anchored scales. Stockford and B1ssell (1949) sought to improve a rating system for Lockheed Alrcraft Corporation. The orfiginal scale used an evaluational scheme of anchoring. The lnvestigators replaced the original scale with a descriptive scale using behavloral anchorings. They concluded that ratings on descriptive scales were more reliable, less influenced by bias, and show less deviation between raters in leniency and severity than is characteristic of ratings done on evaluational scales.

Thus, from the research we have cited so far, it appears that some characteristics of graphic rating scales are defintely superior, while other characteristics demonstrate I1ttle or no advantage, the inclusion of which would be dependent upon personal preference of the person constructing the scale or the person doing the actual rating. It can be said, thon, that as far as the number of traits or factors is concerned, that a relatively small number of tralts or factors fails to ellcit a thorough assessment of an employee's job performance, while a large number of pactors serve to confuse the rater and do not substantially fac1l1tato the rating process, As a result, the majority of 
rating scales employ a moderate number of factors, usually from flve to elght. Humber of rating scale categories seems to have little influence on the reliabllity of rating scales, and rould seem to be dependent also on the personal preference of those constructing the scale. Type of scale anchoring, however, does seem to have a great deal of influence on rellability. It 18 apparent, first of all, that verbal anohoring is superior to numerical anchoring and that the more scale categories anchored verbally, the better. Also, it has been shown that behavioral anchoring is superior to simple evaluative anchoring. For the purpose of this study, 1t was declded to choose a rating scale which possessed characterlatics which have been shown to be superior by re Bearch and which had had research performed on it itself. The graphic rating scale eventually chosen for the study was Format III, published and developed by Personnel Re-... search and Development Corporation; Cleveland, Ohio. 


\section{OEAPTER III}

\section{PORMAT III: RESEARCH}

Format III was the subject, along with three alternative formats, of a serles of studies performed by Barrett, Taylor, Parker and Martens (1958). The four formats, know 28 Formats I,II,III and IV, varied from unstructured to b1ghly structured, and were tested for inter-rater rel1ab111ty, halo, lenlency and variab111ty. All four formats attempted to obtain measurements on seven traits or charac$\operatorname{ter1st10s}$

1. Ab1lity to work with others,

2. Amount of work done,

3. Quality of work done,

4. Leadersh1p potential,

5. Ablilty to do complicated jobs,

6. Ability to work with minlmum supervision,

7. Consclentlousness, and

8. Overall performance.

Format I used only trait names with no legend or numerical scale provided. Format II used a verbal description of the sereral traits instead of trait titles, again with no legend or numer1cal guide provided. Format III contained trait names, no trait descriptions, and behavioral descriptions of the kind of bohavior which characterized each of the flve major divisions of the scale. Format IV contained trait descriptions but no tralt names and the same behavioral descriptions of the polnts of the scale used 
In Format III. On all four formats, raters placed a checkmark at the desired point on a ten inch line divided by vertical markers into five major divislons, which, in turn, were subdivided into three equal sections with no legend or numerical scales provided. Intrarater reliabllity coeffis clents were computed on each of the elght scales for the four different formats. The average correlation for all formats ranged from .51 to .67 with Format III clesrly the best. The rellabilities for all scales were uniformly higher for Format III than for the other formats. The investigators wrote;

The greater stability of Format III makes 1t more widely useful than the other formats since it might happen that an investigator would be more interested in the information in one of the areas which is unreliably measured by one of the other formats. On Format III he would always have available a measure w1th adequate reliability for most purposes. ( $p .340$ )

Raters also showed less lenlency on Format III when means and measures of skewness of each of the four formats were compared. Halo was measured by taking the average intercorrelations of each of the four formats. Format III was ahorn to have a slight superiority over Format IV in this respect. Variability was measured by computing the means and standard deviations of each format. It was decided beforehand that with a mean of 8.0 , a standard deviation of 2.5 would have been 1deal, making 1t possible to extend the scale from -3 to +3 . Instead of following the pattern usually expected of this type of rating scale, 
namely, that the varlability would be less than desired, it was found that most standard deviations clustered between 2.4 and 3.0. The invest1gators themselves were a bit surprised at this; "It turned out, however that the supervisors' ratings were, on the average, slightly more variable than had been anticipated even when a trait name had been used." They propose that perhaps the instructions given to the raters may have had some influence on this phenomenon. Rater's were told to use all the steps of the scale and not to hesitate to use the extremes if they reflected the true behavior of the ratee. Since all the measures of variability were very similar for all the formats, the investigators concluded that the differences in formats did not effect variability systemat1cally.

Format III was used by these same researchers in a later study to be discussed which was, in part, the basis of the present study. In summary, for the above reason and because format III seems to possess all the necessary qualities for a suitable research tool, permission was sought and obtained from Personnel Research and Development Corporation (PRADCO) for the use of this format. 


\section{OHAPTER IV}

\section{THE PROBIEM}

\section{RATER AND RATEE OONPIIOT}

Unlike most other measurements of human behavior, performance appraisal systems, as used in industry, are, in varyling degrees, serles of subjective judgments by someone other than by the ratee. The subfect of other measuring techniques, however, is directly involved in the appraisal process. It is the subject's own responses on the MMPI, for example, which determine his personality profile, and it is his responses which determine his score on a general abllity test. While testees in these circumstances may disagree with the validity or importance of such measures, he is not entirely subject to another person's appraisal of his performance as he is with most rating systems used in industry. While most employees would agree that some form of appraisal system is necessary, and do appreclate knowing where they stand, it is inconcelvable that they would entirely agree with some of the end results of such a system, no matter how it is implemented. Hence, when rating results are communicated, typically within the structure of an appraisal interview, conflicts are bound to arise due to the differing perceptions, attitudes and needs 
which rater and ratee bring to the interview. Meyer, Kay and French (1964), reviewing performance appraisal techniques at General Electric Company, found that the tradit1onal interview technique consisted mainly of the rater Justifyling his ratings and the ratee acting with defensiveness to any criticlsm on the part of the rater. As would be expected, they found that the more criticlsm a man received, the more defensively he reacted in the form of dental of shortcomings, blaming others and vartous other forms of excuses. The investigators concluded that a new proposed system called the work-planning and review method, (WP\&R), with 1ts emphasis on mutual goal setting and problem solving, would help to alleviate thls defenslveness. Earlier, MeGregor (1957), in his analysis of the traditional performance techniques, had proposed a simllar approach; placing greater responsibility on the subordinates for establishing performance goals and appraising progress toward them, tinus stimulatiag the development of the subordinate. Burke and W11cox (1969), in their review of the literature concerning appraisal interview techniques, found that success was related to a bigh level of subordinate particlpation, a belpful and constructive attitude on the part of the supervisor, solution of job problems and the mutual setting of specific goals to be acelved by the subordinate in the near future.

The above studies exemplify the attempts that have 
been made to soften or minimize potential conflict when rater and ratee face each other with the ratings facing both of them. The basic problem lies in the differing conceptions held by each of the current job performance by the ratee and more speclfically, the differlag conceptions of the importance of certain job factors, traits and behavior which contribute to job performance. These differences could very well become disproportlonate due to the importance the ratee attaches to the ratings, upon which $\because$ : some very real declsions could be based.

Performance appraisals can be viewed, then, as subjectlve evaluations reflecting rater or supervisors' ldeas of how certain behavior by the ratee contributes to those characteristics which are essential to good job performance and naturally are not a reflection of subordinates' ideas about that same behavior and how 1 t contributes to job performance. Rarely has the subordinate's own conceptions been regarded as something worth exploring. . Some essence or these conceptions could be obtained quite easily by instructing employees to rate themselves using the same rating forms used by their superviosrs. It would be expected that these self-ratings, when compared with supervisors' ratings, would clearly and directly demonstrate the discrepancies between employee and supervisor perceptions of job performance. The nature and degree of this discrepancy In general and the difference of such between low-rated and 
h1.gh-rated employees is to be explored in this study.

\section{EMPLOYSR-EMPLOYEE DISCREPANCIES IN PERCEPTION}

\section{General Patterns}

The discrepancy between subordinate and superior (or management) perceptions of job performance 18 an element in a general pattern of a well documented discrepancy in the perception of subordinate needs, wants and values. In a well known study by Kahn (1959), It was found that management consistently overestimated the importance workers attach to wages and generally underestimated the importance of soclopsychological needs. Gluskinos and Kestleman (1970) had factory workers, management personnel, and offlce employees list a number of job factors in order of importance to them. They also requested that management and union representatives rate the same factors as they belleved the employees would. Value hierarchles of the factory and ofIice workers were quite different beyond general agreement on the need for steady work. Both management and and union leaders held Inaccurate perceptions of employees' wants by overestimating their needs for material rewards and undereatimating the importance workers attach to good relations with peers and supervisors.

1 study by Bescoe and Lawshe (1955) compared the perception of consideration and iritiation of structure in foremen by superiors and subordinates. That superiors and 
subordinates have very different conceptions about what type of behavior is representative of these two traits is evidenced by the findings that superior-perceived consideration and subordinate-percelved consideration correlated only .02. Ilkewise, the two groups' perception of initiation of structure correlated .04. An involved study by Jensen and Morris (1960) supports the belief that superlors do not percelve in their subordinates as a group those abilities which superiors value most in their contribution to overall job performance. Forty-two male fanttors were ranked by their supervisors according to overall job performance. The fanttors were then rated on the 120 1tems of the Wrigley scale. Items correlating positively with the original rankings were scored as +1 , while those correlating negativeiy were scored as -1 . Algebralc totals for each of the ten factors measured by the Wrigley scale were converted to percentages of the bighest scores possible. On the basis of these percentage scores, two extreme groups were chosen. The individual ten factor scores for these two groups were then compared to each other and to the scorestof the total group. Relative Importance of the factors as percelved by the superlors was shown by the order of the size of the differences between the superior and inferior groups. A correlation of -.92 was found between mean factor scores of the total group and the order of importance of those factors as evidenced 
by the ratings of superior and inferior groups. This indicates that the abilities valued most by the supervisors were least abundant in the workers.

Differences in perception of job performance: self-ratings

Comparatively little research has been performed on the differences in peroeption of job performance between superiors and subordinates in the industrial setting by comparing self-appraisals by employees with appraisals by their superiors. As stated earlier, such an approach would concelvably offer clues as to the exact nature and degree of the discrepancies between superior and subordinate perceptions of fob performance. At least one investigator has stressed the 1mportance of such research. Thornton (1968) states that self-appraisal systems are gaining more and more prominence and that

the relationship between supervisory ratings and self-ratings has important implications for the usefulness of self-appraisal programs. If selfevaluations are to be effective in enlisting a person's cooperation and participation, it seems essential that his perceptions agree with those of his superior. This study was designed to ldentify those areas of executive performance where there might be sigalficant amounts of disagreement. Knowleage of these problem areas would then be ugeful in conducting self-appraisal programs.(p.441)

It should be noted that Thornton was concerned with this problem at the executive level, but it is quite clear that such research has important implications for lower level employees also. In addition to the importance this type of research would have on the future use of self-evaluation, 
which $18 \mathrm{sin}$ attempt to foster subordinate particlpation in the appratsal process, it would serve also as a starting polnt from which management can evaluate the effectlveness with which it communicates what type of behavior it believes best contributes to job effectiveness and, ultimately, organizational effectiveness. Maher and Piersol (1970) found that to the extent that an individual clearly percolves his individual job objectives, his satisfaction with the job will be high. The authors view this as a satisfaction of a higher order need which should be attended to now that increasing affluence is satisfying lower order needs. Self-ratings might give management the feedback it needs to further clarify job objectives.

Self-ratings have gained what little prominence they have not so much as an alternative to traditional rating systems, but rather as a research tool. Although selfratings have been used in confunction with supervisory ratings in a number of studies (Bassett and Meyer,1968), (Hall, 1951), (Robinson, 1970), there is a general tendency of employees to understandably modify their ratings downward somewhat if it is known that their supervisor is to see the ratings and that they may be used in a performance appraisal interview. As a result, this method ylelds modlfled ratings rather than true self-ratings. It becomes clear that if research into the discrepancy between supervisor and subordinate perceptions of job performance is to 
be of any interest or value, then the opportunity ought to be presented to supervioors and employees to keep their ratings confidential, hopefuliy minimizing the need on the part of elther group to modify their ratings in any way. such an approach was chosen for thls study.

Much of the research associated with self-ratings has used them in confunction with supervisory ratings for use in a problem solving, goal-setting performance appraisal interview. Although, as stated above, such a method ylelds somewhat modified ratings. It is still possible to draw some conclusions about characterlstics of self-ratings, and the discrepancy between self-ratings and supervisory rating results. One of these characteristics is, of course, the tendency of employees to overrate themselves. Meyer, Kay and French, in trying to explain the defensiveness in performance appraisal interviews, stated that this tendency on the part of employees might very well account for a good proportion of this defensiveness. The average employee's self estimate of performance before the interview placed him at the 77th percentile. Only two out of the 92 part1cipants estimated their performance to be below the average point on the scale used. It is interesting to note that, after the interview, the same men, when asked how they thought their bosses had rated them, gave a figure that averaged at the 65th percent1le. Parker, Taylor, Barrett and Martens (1959) also found that employees on the... 
vhole rated themselves above their supervisors' ratings on all seven of their job performance factors and on the elghth over-all performance factor. Thornton, in his study, also found the same phenomenon among management personnel. Parker and his associates also found that estimates of supervisory ratings by employees on the average were consistentIf lower than self-ratings on the same factors, but atill hlgber than supervisors' actual ratings. So it appears that, wh1le employees realize that thelr self-ratlings are higher than supervisors' ratings, their estimate of supervisors' ratings reveal that they do not real1ze the discrepency is as great as it is.

on the basis of these studies, the following hypothesis was proposed: On the whole, employees will rate themselves higher than their estimate of supervisors' ratings, whlch, in turn, will be higher than the actual ratings by supervisors.

\section{Group Differences}

It is expected, of course, that there will be differences among employees and groups of employees in the degree of discrepancy between self-ratings and supervisors' rating scores. The subject of individual or group differences in this area has recelved little attention. One investigator, Musella (1969), found that with student teachers, closeminded subjects tended to rate themselves higher than openminded subjects, suggesting at least one personelity $1 \% \cdots$ 
varlable at work. Although the area of personallty variables promises to stimulate new interest and research, it was declded that the present study would compare groups of employees according to their standings on supervisors" ratings; that is, to compare low-rated employees with highrated employees. Thornton took this approach in his study on management personnel. He found that, in general, lowrated employees rated themselves higher than thelr supervisors rated them to a greater degree than did high-rated employees. No sifilar approach, to the knowledge of the writer has ever been taken with non-management personnel. It was expected, however, that the same pattern would emerge. Thus, 1t was hypothesized; both bigh and low-rated employees will rate themselves higher than their estimates of their supervisors' ratings, which will be higher than the actual ratings by supervisors, but high-rated employees w111 show less discrepancy between their ratings (estimate) and supervisors' ratings than will low-rated employees.

\section{Group Differences: Importance of Job Factors}

Certain job factors and traits of employees contribute in varying degrees, of course, to an overall rating of general job performence. Factors on Formet III such as Quant1ty of work or Quality of work would seem, at first glance, to contribute more to overall performance than would factors such as gooperativeness or Conscientiousness. 
Enployees can be rated on a number of traits or factors on a graphic rating scale similar to format III and the relati. tIve weight of each factor can be systematically determined by comparison with an overall estimate of general job performanco. Parker and his assoclates used multiple regression to empirically determine the welghts each group gave to each of the factors on Format III. A s1milar approach was selected for the present study. Using this method, it is possible to ascertain the relative weights given to certain selected factors by employees in their rating of themselves, their estimate of how their supervisors rate them, and the welght given those same factors by supervisors in their ratings of employees. Parker and h1s colleagues did fust that in the study referred to above and discovered differences between supervisors and employe es as a whole. One purpose of this study was to compare the relative weights given factors by low-rated and highrated employees with those given by their supervisors and with each other.

One plaustble reason why some employees are given blgh ratings by their supervisors might be that the rela- $\because$ tive importance attributed to factors in their contribution to overall performance given by these employees might be more simliar to the importance their supervisors attach to these same factors. This line of thought loads naturalif to a third hypothesis; the relative weights given 
cortaln factors in their contribution to overall performance will differ or show more discrepancy between ratings by low-rated employees and supervisors' ratings than betwoen ratings by high-rated employees and supervisors' ratings.

III. STATEMENT OF HYPOTHESAS

From ratings gathered by the graphic rating device, Format III, by supervisors rating employees, by employees rating themselves, and by employees estimating what their ratings by their supervisors will be, the following hypotheses are proposed:

\section{Hrpothesis I}

Bmployees rate themselves higher than their estimate of supervisors' ratings, which, in turn, will be higher than the actual ratings by supervisors.

Bypothesis II

Both high and low-rated employees will rate themselves higher than their estimate of supervisors' ratings which will be higater than the actual ratings, but high-rated emplogees will show less discrepancy between thelr estimate ratings and supervisors' ratings then will low-rated employees.

\section{Hypothes1s III}

The relative weights given certain factors in their 
contribution to overall performance will differ or w1ll show more discrepancy between ratings by low-rated employees and supervisors' ratings than between fatings by highrated employees and supervisors' ratings. 


\section{CHAPTER V}

\section{MTTHOD}

\section{TEE RATING FORM}

The basic rating form is 1denticel to Format III. Formet III, as described earlier, consists of elght rating scales, seven of whlch are designed to cover distinct areas of job performance and the elghth belng an overall, general job performance rating. The rating form, without Instruction pages, consisted of four 8 t by 11 inch pages, each page with tro of the rating scales. Each scale was ten inches long, divided into five equidistant divisions, each with three further subdivisions.. The tra1t name for each scele appears above and to the left of the scale. The verbal anchoring appeared directly below the five major divisions. A copy of the rating form appears in the append1x.

\section{SUBJECTS}

Ratees consisted of 78 femele production workers in elght different work groups at Tektronix, a large electronlcs manufacturing flrm located in Beaverton, Oregon. Subjects engaged in essentlally the same type of work involving the assembly of osc11loscoper. Raters consisted of 
the elght 1mmediate supervisors, all male, of each of the groups of employees mentioned. Company officlals provided ovidence that the groups did not essentially differ from one another in educational background, rate of pay and rate of production.

\section{PROCEDURE}

Bach supervisor was given one rating form for each employee under him along with an instruction sheet, a copy of whlch may be found in the appendix. In short, supervisors were asked to rate each exployee under h1s supervision using the given rating forms following the general outline included with the instructions. No strict time IIm1t was given for completion of the ratings, although each supervisor was asked to return the completed ratings within a reasonable amount of time.

Bach employee particlpating in the study was given two rating forms, each with 1ts own instructions. The P1rat set was used for the employees' oelf appraisals, inile while the second set was used for the employees' estimates of how they thought their supervisors had rated them.

Eight different half-hour sessions were held throughout one workday morning for the purpose of administering the two rating forms to the employees. Participants in the study were pre-assigned to a pertlcular session by theix supervisors and were told only to report to a 
conference room near their work area at their assigned time. Employees in each session were seated around a large oval table and were given a brief oral presentation, a copy of which may be found in the appendix. Following the presentation, each particlpant was given a copy of the first set of ratings and asked to ralse their hand upon completion, after which they were given the second set of. ratings. The employees were not told the purpose of the study, nor were they aware of the instructions for the second set of ratings before they had completed the first set. No time limit was given, although most forms were completed well within 20 minutes. Participants in the study were told they could leave the room after completion of the second set of ratings and were asked to keep detalls of the study from their co-workers.

\section{Scoring}

The raw score on each rating scale was determined by measuring the distance in sub-division units from the left end of the scale to the point on the scale where the rater $\leadsto$ had placed a checkmark. All distances were rounded off to the nearest tenth of a undt. 
CHAPTER VI

RISULTS

I. HYPOTHESIS I

Means and standard deviations of the scores of each of the elght sciles for the three types of ratings were computed and are presented in Table I.

\section{TABIE I}

MEANS AND STANDARD DEVIATIONS OF SCAIE SCORES OF THE THREE TYPES OF RATING USING FORMAT III $(\mathrm{N}=78)$

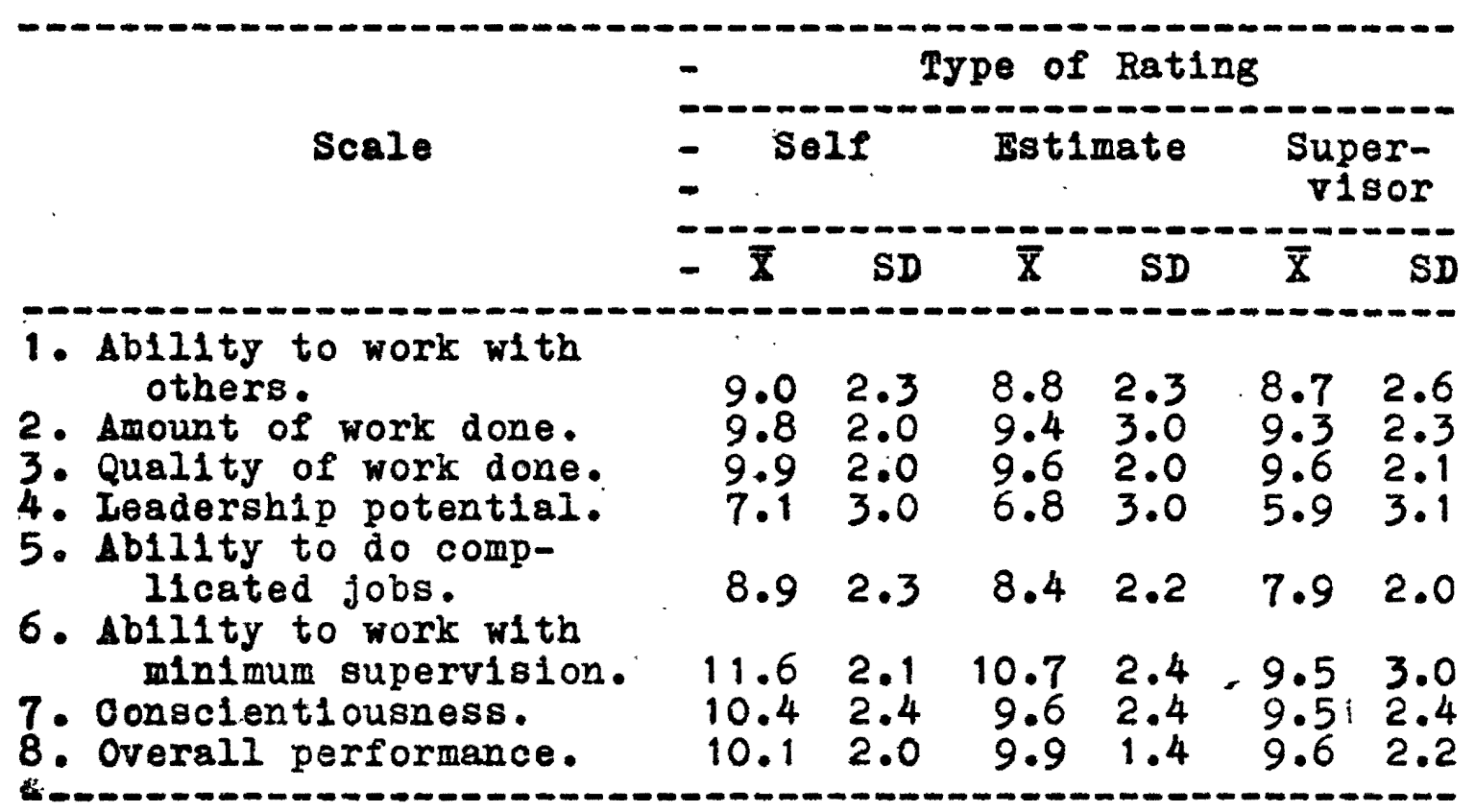

As can be seen from the data, the scores for all scales exoept 3, Quality of work done, follow the pattern predicted in Hypothes1s I; that 1s, the mean of the self 
ratings wes greater than the mean of the est1mate ratings which were, in turn, greater than the mean of the supervisors' ratings. Th1s general ordering of means was tested using Page's (Page, 1963) test for the ordering of means. The above mentioned pattern was found to be signiflcent for scales $4(I=971, P<.05), 5$ ( $I=983, P<.01), 6$ $(I=1003, P<.001)$ and $7(I=977, P<.01)$. The hypothesized ordering of all scores on scale 8, Overall Performance, was tested using Page's test and also found to be significant ( $I=979, P<.01)$.

II. HYPOTHESIS II

The division of the 78 ratees into high, Iow and midde thirds was based on the standard scores of the Individual rating scores using the means and standard deviations of the scores of the elght supervisors. The means and standard deviations of the scores of each of the three ratings for the highest and lowest thirds are shown in Table II along with the mean differences between self-est1mate rating and supervisors' ratings.

Hypothesis II predicted that the lower group would show more discrepancy between their estimate ratings and oupervisors' ratings than would the higher group. Though the discrepancies for the two groups are in opposite directlons (bigher group underestimated, lower group overestimated), the difference in the absolute amount of discrepancy 


\section{TABLE II}

RATINGS ON FAOTOR 8 FOR UPPER

AITD IOWBR THIRD EMPLOYEES

Type of Rating

\begin{tabular}{|c|c|c|c|c|c|c|c|}
\hline \multirow{4}{*}{$\begin{array}{l}\text { Upper } \\
\text { thira } \\
\text { Iower } \\
\text { third }\end{array}$} & \multicolumn{2}{|c|}{ Self } & \multicolumn{2}{|c|}{ Estimate } & \multicolumn{2}{|c|}{ superv1sor } & \multirow{2}{*}{$\begin{array}{l}\text { Mean } \\
\text { Discrepancy } \\
\text { Est.-Super. }\end{array}$} \\
\hline & $\bar{x}$ & SD & $\overline{\mathrm{x}}$ & SD & $\overline{\mathrm{X}}$ & SD & \\
\hline & 9.75 & 2.2 & 9.53 & 2.4 & 11.89 & 1.3 & -2.36 \\
\hline & 10.03 & 1.7 & 10.02 & 1.6 & 7.40 & 1.2 & +2.62 \\
\hline
\end{tabular}

(.26) does not even approach significance. The lower group did not show significantly more discrepancy as had been predicted.

Hypothes1s II also predicted that for both groups, self-ratings would be higher than supervisors' ratings, and that estimate ratings would be less than self ratings, but bigher than the actual ratings by supervisors. Th1s pattern was shown to be true only of the lower group ( $I=$ $342.5, \mathrm{P}<.001)$. The high group rated themselves sign1f1cantly lower $(t=4.28, P<.001)$ than their supervisors' ratings and estimated their ratings to be significantly lower $(t=4.37, P<.001)$ than their supervisors' ratings.

That neltber group of employees nor the employees as a whole demonstrated a moderate .. much less a significant relationship between their self-ratings and supervisors' ratings is shown by the low correlation coefficlents in Table III. Nor does there appear any significant increase 
TABIE III

OORRELATIONS BETWEEN RATINGS ON FACTOR 8 IOR UPPER AND IOWER THIRD EMPIOYEES

$\begin{array}{lcc} & \text { self.-super. } & \text { estimate-super. } \\ \text { Upper third } & .12 & .16 \\ \text { Lower third } & .06 & .16 \\ \text { All groups } & .02 & .22\end{array}$

In the relationship for elther group in the shift from self to estimate ratings.

The results do not seem to indicate support for the hypothesis that high-rated employees show less discrepancy between their estimate ratings and ratings by their superv1sors than do low-rated employees.

\section{HYPOTHESIS III}

Intercorrelations of rating scores for the elght factors used were computed for the self-ratings by high and low-rated employees as well as for the supervisors' ratings. Matrices of these obtained correlations are presented in the appendix. In order to determine the relative welghts given by each of the three groups to the first seven factors in their contribution to Factor eight, overall performance, the step-wise regression analysis method was chosen. This method flrst chooses the variable which oontributes most to the varlance of the dependent variable, 
41

and then, in each additional step, adds another variable which next contributes the most variance and decreases the mean sum of squares. The final step of analysis includes 211 seven variables along with their relative beta-we1ghts, each representing the approximate importance attached to that variable in its contribution to the overall performmande rating by each group. Tables IV, $V$, and VI on the following pages are summaries of the stepwise analysis for each of the three groups. Included are the progressive steps in the multiple regression correlation coefficient, $R$ and its square, $R^{2}$. 
TABIE IV

SUMMARY OF STEPWISE REGRESSION ANALYSIS OF RATINGS BY HIGH-RATED EMPLOYEES

Variables

6. Ability to work with minimum supervision

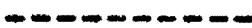

2. Amount of work done

6. Ability to work with minimum supervision

2. Amount of work done

3. Quelity of work done

6. Ab1lity to work with minimum supervision

2. Amount of work done

3. Quality of work done

6. Ability to wark with minimum supervision

7. Conscientiousness

2. Amount of work done

3. Quality of work done

4. Leadership potent1al

6. Ab1ilty to work with minimum supervision

7. Conscient1 ousness

2. Amount of work done

3. Quality of work done

4. Leadersh1p potent1al

5. Ability to do complicated jobs

6. Ability to work with minimum superviston

7. Conscientlousness

1. Ab1lity to work w1th others

2. Lmount of work done

3. Quality of work done

4. Leadership potential

5. Abllity to do complicated jobs

6. Ability to work with minimum

$$
\text { suparvision }
$$

7. Conscientiousness
BetsCoefficient

Nultiple

$R$ R $R^{2}$

$\begin{array}{llll}.7772 & .777 & .604 \\ .4104 & & \\ .6264 & & .866 & .750 \\ .3722 & & \\ .2253 & & & \\ .4955 & & .882 & .778 \\ .4030 & & & \\ .0424 & & \\ .5422 & & & \\ -.0981 & & .884 & .782 \\ .4079 & & \\ .2329 & & \\ .0774 & & \\ .5482 & & . \\ -.1383 & & .887 & .786 \\ .3803 & & & \\ .2099 & & & \\ .0707 & & & \\ .0702 & & & \\ .5281 & & & \\ -.1331 & & .888 & .788 \\ -.0419 & & \\ .3974 & & & \\ .2202 & & & \\ .0686 & & & \\ .0736 & & & \\ .5248 & & & \\ -.1354 & & .889 & .790\end{array}$




\section{TABIE V}

SOMMARY OF STEPWISE REGRESSION ANAIYSIS

OF RATINGS BY IOH-RATED ENPIOYERS

\section{Varlableo}

2. Amount of work done

1. Ability to work with others

2. Amount of work done

1. Ability to work with others

2. Amount of work done

7. Consclentiousness

1. Ablility to work with others

2. Amount of work done

4. Ieadership potential

7. Conscientiousness

1. Ablilty to work with others

2. Amount of work done

3. Quelity of work done

4. Leadership potential

7. Conscientiousness

1. Ability to work with others

2. Amount of work done

3. Quality of work done

4. Ieadership potential

5. Ablilty to do complicated jobs

7. Conscient1ousness

1. Ab1lity to work with others

2. Amount of work done

3. Quality of work done

4. Leadership potential

5. Abtlity to do complicated jobs

6. Ability to work with minimum

$$
\text { supervision }
$$

7. Consclentiousness
$\underset{R}{\text { Bets- }} \underset{R}{\text { Multiple }} R^{2}$

$\begin{array}{lll}.7685 & .768 \quad .591\end{array}$

.1857

.6841

$.786 \quad .618$

.2647

.7721

$-.2095$

$.801 \quad .642$

.2973

.7812

.2309

$-.3807$

$.820 \quad .672$

.3347

.8433

$-.1135$

.2037

. .3868

$.824 \quad .679$

.4319

.9532

$-.2477$

.1026

.2173

$-.4999$

$.837 \quad .700$

.4660

1.0126

. .3221

.1114

$-.2523$

.1023

$-.5875$ 
TABLE VI

SUMMARY OF STEPWISE REGRESSION ANALYSIS

OF RATIYGS BY SUPERVISORS

\section{Variables}

7. Consclentiousness

6. Ab111ty to work with minimum supervision

7. Conscientiousness

2. Amount of work done

6. Ability to work with minimum supervision

7. Conscient1 ousness

2. Amount of work done

3. Quality of work done

6. Ability to work with minimum supervision

7. Conscientiousness

$-----m-$

2. Amount of work done

3. Quality of work done

5. Ability to do complicated jobs

6. Ability to work with minimum supervision

7. Conscientiousness

1. Ability to work with others

2. Amount of work done

3. Quality of work done

5: Ability to do complicated jobs

6. Ability to work with minimum 8 upervision

7. Consc1ent1 ousness

1. Ab111ty to work w1th others

2. Amount of work done

3. Quality of work done

4. Leadership potential

5. Ability to do complicated jobs

6. Lbility to work with minimum

supervision

7. Oonscientiousness
Beta- Mult1ple Coefficient $R$ $\mathrm{R}^{2}$

$.9071 \quad .907 \quad .823$

.3172

.6593

$.928 \quad .862$

.2121

. 2796

- 5288

$.939 \quad .881$

.1731

.1492

.2242

.5080

$.945 \quad .892$

.1700

.1391

.0635

.2005

.4936

$.946 \quad .894$

.0408

.1711

.1363

.0600

.1822

.4945

$.946 \quad .896$

.0490

.1679

.1288

$-.0344$

.0693

.1925

.5046 
To facilitate comparioons of the final beta-weights among the three groups, the flnal welghts are presented in Table VII, along with the results of tests of sigalficance of beta from zero, final multiple $R$ and $R^{2}$.

\section{TABIE VII}

BETA-WEIGHTS FOR EACH FACTOR WITH MULTIPLE

OORRELATIONS (R) BETWEEN TACTORS 1 THROUGH 7 WITH FACTOR 8

Beta-welghts

Pactor

1. Ability to work with others

2. Amount of work done

3. Quality of work done

4. Ieadershlp potent1al

5. Ability to do complicated jobs

6. Ab111ty to work with minimum supervision

7. Conscientiousness

$-\infty-\infty$

Multiple $R$

$$
\mathrm{R}^{2}
$$

Iow

H1gh

Supervisor

\begin{tabular}{|c|c|c|}
\hline $.47 *$ & -.04 & .05 \\
\hline $1.01 * *$ & $.40 *$ & $.17 * *$ \\
\hline-.32 & .22 & $.13^{*}$ \\
\hline .11 & .07 & -.03 \\
\hline .25 & .07 & .07 \\
\hline .10 & $.52 * *$ & $.19 *$ \\
\hline$-.59 *$ & -.14 & $.50 * *$ \\
\hline .8408 & .8886 & .9466 \\
\hline .7070 & $\begin{array}{r}.7896 \\
-1 \mathrm{P} \\
* \mathrm{P}<\end{array}$ & .8961 \\
\hline
\end{tabular}

.... $\Delta$ s can be observed from Table VII, the bigh-rated employees seem to show more correspondence in thelr final 
beta-reights to the supervisors than do the low-rated employees, with the notable exceptions of Factors 6 and 7 , Ablity to work with minimum supervision and conscientiousness. The results for Factor 6 are decelving, however. Among supervisors this was show to be the most important factor after conscientiousness, while with blgh-rated employees it was the single most important factor. Lowrated employees show it to be the least important factor. Both high and low-rated employees glve Factor 7 , Consclent1ousness, the heaviest negative weight, while supervisors give it the highest positive weight.

Very high multiple Rs were fourd for all groups in the study, suggesting that the seven factors in question account for a large amount of the variance in the Overall performance ratings. Other factors accounted for $29 \%$ of th the varlance in ratings by low-rated employees, $21 \%$ in ratings by high-rated employees and only 10\% in ratings by the supervisors. Thls suggests that there were other factors which contributed to job performance in the eyes of the employees of which the supervisors were unaware. Few of the final beta-weights were found to be significantly different from zero; two among high-rated emilo ployees, three among low-rated employees, and four among Bupervisors. Individual beta-welghts showed much less variance among supervisors, thus requiring lower beta values for signiflcance. 
As can be seen from Trbles IV, $V$ and VI, a 11mited number of factors can account for almost ali the variance In Factor 8, Oyerall performance, contrlbuted by all seven factors together. For high-rated employees, Factors 2,3 and 6, Amount of work done, Quality of work done and Ab1Ilty to work with minlmum supervision, together accounted for $77.8 \%$ of the rarlance, which was $98.6 \%$ of the variance accounted for by all seven variables. For low-rated employees, Factors $1,2,4$ and 7, Ablity to work with others, Amount of work done, Leadership potent1al and Conscient1ousness accounted for about $67.5 \%$ of the variance or 95.19 of that accounted for by all varlables. For the supervisorg, Factors $2,3,6$ and 7, Amount of work done, QuaIity of work done, Ability to work with minimum supervision and consclentiousness accounted for $89 \%$ of the var1ance or $99.6 \%$ of the total variance accounted for by all aeven factors. Consclentlousness alone accounted for $82 \%$ of the variance in Factor 8.

That the hlghirated employees shared three of the four factors considered important by supervisors again shows the closer correspondence between conceptions of what contributes to. job performance and that of their supervisors. Low-rated employees shared two of the four factars considered important by supervisors, but it must be polnted out that Factor 7 , Oonscientiousness, possesses a very strong negative weighting for low-rated employees, 
but a very positive weighting for supervisors.

Paotor 1-Ab1l1ty to work w1th others-carries:11ttle or no weight with high-rated employees and supervisors but is a very definite contributor to job performance among low-rated employees. Apparently, low-rated employees overeatimate the importance of their relationships with coworkers in its contribution to overall performance.

Factor 2--Amount of work done--1s a consistent contributor to job performance across all groups. It carries the beaviest amount of welght of any of the factors covered among low-rated employees, and a fair amount of weight among blgh-rated employees and supervisors. AII groups seem to recogaize the importance of this factor in contributing to overall job performance.

Factor 3--Quality of work done--1s given slight welght by high-rated employees and supervisors and a fair negative welght by low-rated employees, who seem to undereatimate the contribution of this variable and indeed assign a negative weight to it, a result which is hard to interpret.

Factor 4--Leadership potential--carries l1ttle or no welght for high-rated employees and supervisors and only a slight welght for low-rated employees. None of the groups consider this factor to be of major importance. Factor 5--Ability to do complicated jobs--carries little or no weight among high-rated employees and 
supervisors, but a fair amolint of welght among low-rated employees: Apparently, low-rated employeés belleve that 11 they have the abillty to perform a job a blt more dif11cult than their present job, then it ought to contribute to present job performance.

Factor 6--Ability to work with minimum supervision-18 given heavy weight by high-rated employees, moderate welght by supervisors and 11 ttle welght by low-rated emplojees. High-rated employees seem to overemphasize and low-rated employees seem to underemphasizo the contribut1on of this variable to overall performance in relation to that attributed by supervisors in their ratings.

Pactor 7--Conscientiousnese-1s grossly underestimated by both groups of employees. Supervisors welghted this factor as the single most important in contributing to overall performance, whlle both groups of employees gave this factor negative weighting. This suggests that employess elther have conceptions of what this factor means which are very different from that of their supervisors, or that they have perhaps simliar coneeptions, but disagree greatly on 1ts importance.

It was decided to investigate the amount of discrepancy between mean scores between self-ratings and supervisors' ratings for the two groups of employees in relation to the ranked 1mportance of the factors by supervisors as estimated from thelr relative beta-welghts. The 
Spearman rank correlations computed were .43 for low-rated employees and -.25 for high-rated employees. The differences in rank correlations was nonsigniflcant because of the small number of factors and only suggested that lowrated employees tend to show more discrepancy in those factors deemed Important by supervisors. 
OHAPTER VII

\section{DISCUSSION}

\section{IMPIIOATIONS OF THE STODY}

One finding of this gtudy was that employees as a whole demonstrate a higher oplnion of their overall job performance than do thetr supervisors. Employees as a whole also believe that their superviscis have a higher opinion of their job performance than they actualis do. This result was not surprising in view of some of the results from past simjlar studies.

Probably one of the most 1mportant implications of th1s study is that there exist very definite group differences in how emplojees rate themselves and estimate theif ratings by supervisors. In this particular study, groups of employees based on their ratings on an overall performance rating by their supervisors showed about the ame amount of discrepancy between their ratings est1mating their supervisors' ratings and the actual supervisors' ratings. But the most interesting elnding was that the amount of discrepancy was in opposite directions, with lowrated employees overestimating themselves and high-rated employees underestimating themselves to a signiflcant de5ree. If either group enjoyed a more accurate perception 
of how thetr supervisors rated them, it certainly was not demonstrated in this study. Perhaps a tendency toward modesty in the high-rated group caused some downgrading of their self-ratings and estlmate ratings. This tendency, along with a possible leniency effect on the part of supervisors which would increase their ratings might account for a good part of the discrepancy between the ratings of these two groups. Low-rated employees may have been demonstrating some sort of overcompensation for what they realized was their lor standing among their fellow employees. A lack of lenlency with this group of employees on the part of supervisors along with an overcompensation effect might account for a good deal of the discrepancy between these two groups.

Another explanation for the amount of discrepancy between estimated ratings and actual ratings for both groups might be that significant numbers of employees in both groups receive little or no feedback from their supervisors concerning their standing among fellow employees. Ih1s could be 1nterpreted in a number of ways. One interpretation is that employees receive little or no leedback from their supervisors about their job performance at all. This would be a sorry state of affairs and one that is possible, but not probable. Another interpretation is that employees do recelve feedback about job performance, but that it is the type of feedback that is wh thout regard 
to the performance of other workers. Perhaps an employee 1s glven feedback about what she is dolng well on the job but receives no information in the process about her relative standing in the group. If this interpretation were valid, the employee would have to use ber own perceptions about her relative standing to rate herself or estimate her rating on the type of scale presented in this study. Conceivably, personality factors would be at work in this situation in conjunction with feedback from other sources than supervisors; possibly co-workers, pay-scales, etc.. This interpretation, in the opinion of the writer, deserves the most consideration. It may also be, however, that high -rated employees have very different 1deas about the abiIity of their co-woricers than do low-rated employees. High-rated employees, for example, may view other employees as generally below average workers, and themselves as slightly above average, but still above the majority of their fellow workers. Low-rated employees may have a higher opintion of their co-workers as belng much above average, and may consider themselves below this level of their felIow workers, but st111 above average with "average" being very low within this particular group of workers.

The data obtained from this study does not fully support any of the above interpretations. Without further Investigation well beyond the scope of this study, no explanation can be seriousiy attempted. The data do indicate 
definite differences in how two groups of employees, classifled according to how their supervisors rate them, estlmate their supervisors' ratings; differences which. data taken from employees as a whole do not suggest. From the rosults of this study, the notion that employees overostimate their performance appears to be a much too simple and broad generalization.

phough nelther ing nor low-rated employees show any more accuracy in estimating their ranking by supervisors on an overall performance scale, high-rated employeees do demonstrate more awareness of the importance attached to certain job factors by their supervisors. This lends some credence to the notion that high-rated employees are rated h1gh partly because they share many of the same conceptions about the importance given those same job factors, The data do notindicate whether high-rated employees hold these same conceptions independent of any influence from their supervisors, or whether they are botter able to discern their supervisors' ldeals and bring their ow job behavior in line with those 1deals.

In summary, the data give definite evidence of the disparities between employees' concepts of their own job performance and that of their supervisors, along with ev1dence of a closer correspondence between high-rated employees and supervisors in the weight given to certain job factors in their contribution to overall performance than 
between low-rated employees and supervisors. The data also indicate the inability of elther group as a whole to ostimate the ratings given by their supervisors accurately, a particularly surprising result when one considers that mexlt ratings by supervisors in this particular firm are used in a conscientious performance appraisal interview program.

The data also question the value of self-ratings for any other use than as a research tool and, in limlted osses, as a basis for performance review discussions. A neglible correlation between ratings of themselves and by thoir supervisors was found among employees as a whole and in each of the groups of employees studied. This is strong evidence against replacing supervisors' ratings with self-ratings for purposes traditionally associated with performance ratings. Ratings by employees certainly demonstrate no more objectivity than do supervisors' ratings.

Self-rat1ngs do have use, however, in research on employee perceptions about job performance. Information gathered from self-ratings can also give management feedback about employee-management discrepancies in perception, Whether any such discrepancies are of any importance depends upon management aims and objectives. Discrepancies found in the present study, for example, may or may not be of any consequence if management feels employees are 
already working at their potential. on the other hand, management may feel that correcting some misconceptions on the part of employees may also clear up some misconceptions on the part of supervisors and nothing but good can result.

\section{IIMITATIONS OF THE STUDY}

The conclusions and lmplications of this study are, of course limited by a number of factors. The most basic Iimitation is probably the number and type of subjects. All subjects were female; and numbered but 78 in the total group. The division into three groups resulted in groups of only 26. This 1s short of any 1deal number of subjects for a multiple regression analysis. The subjects were production workers, in contrast to most studies involving female workers, in which subjects are generally clerical workers. These results cannot be generallzed to elther the general population of production workers, nor to that of female workers. Also, at the time the study was conducted, the department in question was having an absenteeism problem and management aamittedly was having a difficult time in communicating to the workers the importance of shoring up for work consistently. This may have influenced ratings by supervisors in a indeterminable manner. The rating scale itself demonstrated some limiting factors. A number of scales contributed little or nothing to the variance in Factor 8 , Overall performance. of 
course, each group differed as to which factors they deemed 1 mportant, and the inclusion of all seven factors, whether some of them contributed Ilttie or not, did make it posolble for group differences to show themselves. Although no method was included in the framework of this study to check reliablilty of the scale, there was reas on to belleve that the scale was falriy reliable from evidence of eariler studies. However, in studies such as this, in which group differences are to be examined, precautions should be made to assure that any rating or evaluation system belng used 1. rellable for all groups studied.

Also, this study lgnored a potentially important group for comparative purposes, the middle third rated employees. As the study now stands, what conclusions there are that can be drawn are limited by the fact that they represent only high and low-rated employees.

II. RECOMMENDATIONS FOR FURTHER STUDY

This study leaves many questions unanswered. Perhaps with different and more speciflc approaches to some of the problems posed in this study, more may be leamed about differences among employees and between employees and supervisors in rating job performance and in the importance of certain job factors. Different rating scales with different combinations of job factors might be used to discover if the same pattern found in this study exists 
elsewhere. Larger numbers of subjects should be studied In a number of different circumstances. Perhaps the results of this study are unique with female production workexs; only further research could give the answer.

One result of this study is that striking differences are suggested in the weights employees attach to job factors. In this study, employees were divided according to thelr ratings by supervisors. In future studies, employees could be differentlated by various methods. Employees working under a particular supervisor for a long period of time could be compared with those who have been under the same supervisor for a short period of time. It would have to be predicted that those in the former group would show more agreement with their supervisor's welghting of factors on simllar scales. Groups of employees under differing types of supervision could be compared. Also, the effectiveness of a feedback-communioation program could be evaluated in a closely controlled study.

Factors on whlch supervisors and employees as a whole or as a group taken on some basis from the total group differ considerably should be explored to determine how thelr respective perceptions differ. Consclentlousness, for example, in this study would be prime subject matter for this type of approach due to the abrormally large discrepancles demonstrated between employees and supervisors in their weighting of this factor. 
Differences between employees who definiteig underestimate themselves and those who overestimate themselves ought to be investigated to determine if personality faotors are at play and to what extent they lateract wth other factor. One approach might be to have emplcyea judge the performance of thelr fellow workers as a group. It may be that those rated high according to some independent measure and those rated low have very different ldeas about how thelr coworkers rate as a whole, and where they themselves fit into the general distribution. Perhaps high-rated employees do not really underestimate themselves on an overall performance measure, but rate thelr fellow workers lower, while still consldering themselves among the best workers of their group.

Finally, a similar study ought to be performed in a company that does not use performance review sessions with employees in a lormal program to detarmine if a pattern similar to that found in this study results. Fmployees in such a situation would concefvably show even less correspondence between their self and estimate ratings, having recelved even less feedback or information about their fob performance.

Any study performed in an 1ndustrial setting is limited by the 1nability to lmpose those experimental controls typical of laboratory studies. As a result, conclusions and Implications are ofter not clearcut and definfte. 
60

Nonetheless, no other method exists to study people at work in a scientific manner. This particular study is onIf an introduction to one aspect of the promising study of group and individual differences among employees. Very little data exist in this area of research, and, as a result, the value of such research cannot be gauged by the present state of affairs, but rather what might follow in future studies. 


\section{OHAPTER VIII}

\section{SUMMARY}

The purpose of this study was to gain some insight Into the differing conceptions of job performance and job performance factors held by supervisors, employees in general, and of employees rated high and low on overall job performance by their supervisors. It was suggested that much of the potential conflict present when rater and ratee face each other with the ratings facing both of them is due to these differing oonceptions of what good job performance 10; and how certain factors and behavior contribute to that performance. These differences naturally become disproportonate due to the importance the ratee attaches to the ratings. Several studies were mentloned to exemplify the efforts to soften potential conflict between raters and ratees. It was noted that the discrepancy in the perceptions of fob performance is an element in a general pattern of a well-documented discrepancy in the perception of subordinates' wants, needs and desires.by superiors.

To assess employees' perceptions about their own job performance, self-ratings were taken, along w1th est1materatings of bow employees thought their supervisors would rate them. A graphic rating scale was used, Format III, with seven job performance factors; Abllity to work with 
others, Amount of work done, Quallty of work done, Leadership potential, Ability to do complicated jobs, Ability to work with minimum supervision, Conscientiousness, and an e1ghth scale, overall performance. Serving as subjects were 78 female workers engaged in the sssembly of electronic osellloscopes along with their elght immediate supervisors, all male.

It was hypothesized, on the basis of earlier studies, that employees rould rate themselves higher than their est timate ratings, whlch, in turn, would be higher than the actual ratings by supervisors. This general ordering was found to be significant for all factors except 1,2 and 3 at the .05 level and beyond. The ordering of scores on scale 8, Overall performance, was significant at the .01 level of Bignificance.

It was expected that there would be differences among groups of employees in the degree of discrepancy between estimate-ratings and actual supervisors' ratings. Employees were divided into low and high groups diccording to the ratings given them by their supervisors, with both groups consisting of one-third of the total number of employees. It was hypothesized that low-rated employees would show more discrepancy in thls case than would bigh-rated employees, with both groups overestimating their overall perfor: mance.

Though the discrepancies for the two groups were 
found to be in opposite directions (higher group underostimating, lower group overestimating), the difference in the absolute amount of discrepancy does not even approach statistical slgniflcance. The lower group did not show significantly more discrepancy as had been predicted. Also, the high rated themselves and estimated their ratings to be significantly lower than actual supervisors' ratings. The third hypothesis was based on the assumption that one reason hlgh-rated employees are rated blgh is that the relat1ve importance these employees attach to certain job factors is more similar to that attached by supervisors than those by low-rated employees. Mult1ple regression equations were computed for supervisors' ratings, b1gh-self ratings and low-self ratings using the overall performance rating as the criterion and the other seven factors as predlotor varlables. It was found, as predicted, that highrated employees did show closer correspondence in their welghts to those: given by supervisors than did low-rated employees.

Implications of the study were discussed, with possible explanations proposed for the unexpected results of the second bypothesis with no single explanation found to be satisfactory with the limited amount of data avallable. Recommendations for furtber study were suggested, particularly with different subjects, within a company with no appralsal interview, and with different methods of grouping 
employees.

Some conclusions based on the study, I1mited by the nature and number of subjects and the type and number of factors used in the rating scale are as follows; a) employees, as a whole, rate themselves higher both on a sellrating and on an estimate of their supervisors' ratings than the supervisors actually do rate them, b) neither high nor low-rated employees have any better idea of how their supervisors rate them on overall performance; both groups show approximately the aame amount of discrepancy between thelr estimate of their supervisors' ratings and the actual ratings, c) high-rated employees tend to underestimate themselves and low-rated employees tend to overestimate themselves on overall performance both to about the same degree, d) high-rated employees do seem to have a better: Idea of the job factors that are lmportant in the1r contribution to overall performance than do lowrated employees; the factors high-rated employees, judge to be important are generally the same factors the1r supervisors judge to be important with noted exceptions. 
REFERENCES

Barrett, R.S., Taylor, E.K., Parker, J.H., and Martens, W.I. Rating scale content:I. Scale information and supervisory ratings. Personnel Psychology, 1958, 11,

Barrett, R.S. Performance rating. Chlcago: Sclence Research Associates, 1966.

Bassett, G., and Meyer, H. Performance appralsal based on self-review. Personiel Psychology, 1968, 21, 421-430.

Bendis, A.W. The rellability of self-ratings as a function of the amount of verbal anchoring and the number of categorles on the scale. Journal of Applied Psychology, 1953, 37, 38-41

Bend18, A.W. Rellability and the number of rating scale categorles. Joumal of Applied Psychology, 1954a, 38, $38-40$

Bescoe, R.0., and Iawshe, C.H. Foremen leadership as percelved by superiors and subordinates. Personnel Psych이요․, $1959,12,573-583$.

Blngham, W.V. Halo, invalid and val1d. Journal of Applied Psychology, 1939, 23, 221-228

Bittner, R. Dereloping an industrial merit rating procedure. Personnel Psychology, 1948, 1, 403-32

Burke, R.J., and WIlcox, D.S. Characteristics of effective employmee performance review and development interviews. Personnel Psychology, 1969, 22 (3), 291-305

Ewart, E.S., Seashore, S.E., and TIffin, J. A factor analysis of an industrial merit rating scale. Journal of Applied Psychology, 1941, 25, 481-86

Gluskinos, U.M., and Restleman, B. Management and union leaders' perception of worker needs as compared with self-reported needs. Proceedings of the Annual Convention of the American Psychological Association, T970, $5(\mathrm{pt} .2), 603-604$

Grant, D.I. A factor-analysis of managers' ratings. Journal of Applied Paychology, 1955, 39, 283-286 
Hall, H.B. Tools for improved personnel relations. New York: American Management Association, 1951, 32, 283286

Jensen, N.B. and Morris, W.E. Supervisory ratings and attitudes. Journal of Applied Psychology, 1960, 44, $339-340$

Kahn, R.I. Human relations on the shop floor. In E.M. HughJones (Ed.), Human relations and modern management. Chicago: Quadrangle Books, 1965

Maher, J.R. and Piersol, D.T. Percelved clarity of individual job objectives and of group mission as correlate factors of organizational morale. Journal of Commun1cat1ons, 1970,20 (2), 125-133

McGregor, D. An uneasy look at performance appraisal. HarVard. Business Review, 1965, 43, 123-129

Mejer, H.H., Kay, E.and French, J.R.P. Split roles in performance appraisal. Harverd Buslness Review, 1965, $\rightarrow$ 43. $123-129$

Musella, D. Perceptual-cognit1ve style as related to selfevaluation and supervisor ratings by student teachers. Journal of Experimental Education, 1969, 37 (3), 5155

Page, E.B. Ordered hypotheses for multiple treatments: a algniflcance test for linear ranks. Journal of the Amerlcan Statistical Association, 1963, 56, 216-230

Parker, J.W., Taylor, E.K., Barrett, R.S. and Martens, I. Rating scale content: III. Relationships between supervisory and self-ratings. Personnel Psychology, $1959,12,49-53$

Peters, D.I. and MCCormick, E.J. Comparative rellability of numerically anchored scales versus job-task anchored rating scales. Journal of Applied Psychology, 1966, 50, 92-96

Roach, D.E. Factor analysis of rated supervisory behavior. Personnel Psychology, 1956, 2, 487-498

Roblnson, D.B. Predicting police effectiveness from self reports of relative time spent in task performance. Personnel Psychology, 1970, 23 (3), 327-345 
Seashore, S.X., Indik, B.P. and Georgopoulos, B.S. Relat1onships among eriteria of job performance. Journal of Applied Psychology, 1960, 44, 195-202

Stockford, I. and BIssell, H.H. Factors Involved in establishing a merit-rating scale. Personnel, 1949, Sept, 94-115

Symonds, P.M. On the loss of reliablilty in ratings due to coarseness of the scale. Journal of Experimental Psychology, 1924, I, 456-461

Taylor, E.K. and Hastman, R. Relation of format and administration to the characteristics of graphic rating scales. Personnel Psychology, 1956, 9, 181-206

Thorndike, E.I. A constant error in psychological ratings. Journal of Applied Psychology, 1920, 4, 25-29

Thornton, G.C. The relationship between supervisory and 5 self-appraisals of executive performance. Personnel Psychology, 1968, $21(4), 441-455$

Tiffin, $J$ and McCormick, E.J. Industrial Psychology. (5th ed.) Englewood Cliffs, N.J.: Prentice-Hall, 1965. 
APPENDIX A

MATRIOES OF CORRELATION COEREICIENTS

I. MATRIX FOR SUPERVISORS

$\begin{array}{llllllll}1 & 2 & 3 & 4 & 5 & 6 & 7 & 8\end{array}$

Factor 1

Factor 2

Factor 3

Factor 4

Factor 5

Factor 6

Factor 7

Factor 8

$$
\begin{aligned}
& \begin{array}{llllllll}
1.00 & .35 & .38 & .51 & .41 & .53 & .41 & .47
\end{array} \\
& \begin{array}{lllllll}
1.00 & .61 & .42 & .56 & .65 & .75 & .79
\end{array} \\
& \begin{array}{llllll}
1.00 & .35 & .57 & .65 & .62 & .72
\end{array} \\
& \begin{array}{lllll}
1.00 & .58 & .63 & .59 & .57
\end{array} \\
& \begin{array}{llll}
1.00 & .68 & .65 & .70
\end{array} \\
& 1.00 \quad .78 \quad .83 \\
& \begin{array}{r}
1.00 \quad .91 \\
1.00
\end{array}
\end{aligned}
$$

\section{MATRIX FOR LOH-RATED EMPIOYEES}

Factor 1 Factor 2 Pactor 3 Factor 4 Factor 5 Factor 6 Factor 7 Factor 8

$$
\text { 1 } \begin{array}{lllllll}
2 & 3 & 4 & 5 & 6 & 7 & 8
\end{array}
$$

$$
\begin{array}{lrrrrrrr}
1.00 & .45 & .48 & .26 & .04 & .20 & .57 & .50 \\
1.00 & .58 & .33 & .12 & .13 & .59 & .77 \\
& 1.00 & -.01 & .06 & .39 & .30 & .42 \\
& & 1.00 & .51 & .00 & .54 & .33 \\
& & & 1.00 & .11 & .45 & .11 \\
& & & & 1.00 & .33 & .04 \\
& & & & 1.00 & .40 \\
& & & & & & & \\
& & & & & & 1.00
\end{array}
$$

III. MATRIX FOR HIGH-RATED EMPLOYEES
Factor 1

Factor 2

Factor 3

Factor 4

Factor 5

Factor 6

Bactor 7

Factor 8

1. $\begin{array}{llllllll}2 & 3 & 4 & 5 & 6 & 7 & 8\end{array}$

$$
\begin{array}{llllllll}
1.00 & .48 & .35 & .12 & .39 & .22 & .29 & .34 \\
1.00 & .38 & .24 & .61 & .37 & .56 & .64 \\
& 1.00 & .36 & .65 & .64 & .60 & .69 \\
& & 1.00 & .37 & .34 & .50 & .38 \\
& & & 1.00 & .62 & .59 & .71 \\
& & & & & 1.00 & .70 & .78 \\
& & & & & & 1.00 & .65
\end{array}
$$




\section{APPENDIX $B$}

\section{INSTRUCTIONS}

\section{ORAI INSTRUCTIONS TO EMPLOYEES}

Good Morning. My name is Harvey McGowan and I am a graduate student at Portland State UnIversity working on my master's thesis. As part of the rork involved with my thesis, I amasking you this morning to complete two sets of ratings. The first set I will pass out to you shortIy. It has Instructions of 1 ts ow on the cover sheet. Please note that the instructions refer to two sets of ratings attached. Actually there is only one. The second set of ratings referred to 111 be passed out once you have completed the flrst set of ratings. So, after you have completed the flrst set of ratings, raise your hand and I w11 give you the second set of ratings. Once you have completed those ratings, please bring them to the front of the room, after whlch you may leave. Please bo assured thet these ratings are for research purposes and w111 not be observed by anyone but myself. If there any questions now, or when you are working on the ratings, I shall be glad to answer them. You may begin as soon as you recelve the first set of ratings. Thank you very much for your coogeration. 
II. WRITTEN INSTRUOTIONS ACCOMPANYING FIRST SET OF RATINGS

Accompanying this instruction sheet are two sets of rating forms. You are asked to complete the pirst set and plalsh the set before going on to the second set of ratings.

The first set of ratings consista of seven different job factors or traits and an elghth overall performance rating. Simply place a checkmark at the point along the Ilne which you think best describes your own performance. Here are some guidelines whlch should make your ratings more accurate and easier for you:

1) Try to cons1der each of the seven traits or factors separately; one at a time. Try to keep only one factor in mind when rating and try not to let ratings on any other factor influence you.

B) Do not hesitate to use the extremes on the scales, if they do, in fact, describe your performance as you Bee 1t. However, you should keep in mind that most employees probably are rated somewhere around the middie of the scales.

C) Do not labor over these ratings and spend too much time on them. Spend enough time on each scale to rake what you think will be an appropriate judgment. Studies have shown that if too much time is spent on ratings, raters become confused and the ratings, then become confusing.

Remember that for this first set of ratings, you are rating yourself. Iry to be as honest as possible, and do not read the instructions for the second sot of ratings unt1l you have completed the IIrstet.

Thank you for your cooperation. If there are any questions now or while you are doing the ratings, please 
ralse your hand and someone will assist you. If you have no questions, please begin.

\section{WRITTEN INSTRUCTIONS ACCOMPANYING}

\section{SECOND SET OF RATINGS}

As we all know, not all people see the same thing in the same way. You have just rated yourself on a number of traits and job factors as you see yourself. Your superv1sor, though, may or may not have the same 1dea of how you rate on each of these factors. Would your supervioor rate you differently on this same rating form ?

For this set of ratings, you are asked to estimate how you think your supervisor would rate you. The direct1ons are essentially the same as the instructions for the set you gust finished, except, of course, that you trying to rate yourself as you think your supervisor would. So you should not worry about how you just rated yourself on the previous set of ratings, but concentrate on how you thlink your supervisor would rate you.

If you have no questions, go ahead and begin this set of ratings.

\section{INSTRUCTIONS TO SUPERVISORS}

Instructions to supervisors were essentially the same as those accompanying the first set of ratings for employees, with the same guidelines and 1nstructions; the only changes beling those mentioning self-rating. 